\title{
PHYTOCHEMICAL AND IN VITRO PHARMACOLOGICAL EVALUATION OF PHLOMIS PUNGENS
}

\author{
PHLOMIS PUNGENS'IN FITOKIMYA VE IN VITRO FARMAKOLOJIK ETKILLERININ \\ DEĞERLENDİRILMESI
}

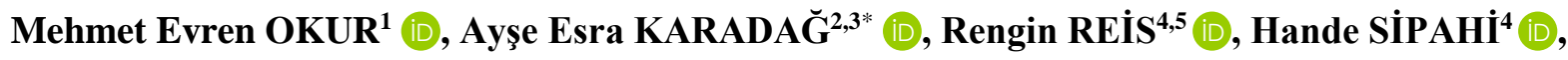

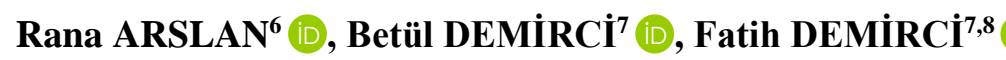
${ }^{1}$ University of Health Sciences, Faculty of Pharmacy, Department of Pharmacology, 34668, Istanbul, Turkey
${ }^{2}$ Istanbul Medipol University, School of Pharmacy, Department of Pharmacognosy, 34810, Istanbul, Turkey

${ }^{3}$ Anadolu University, Graduate School of Health Sciences, Department of Pharmacognosy, 26470, Eskişehir, Turkey

${ }^{4}$ Yeditepe University, Faculty of Pharmacy, Department of Toxicology, 34755, Istanbul, Turkey

${ }^{5}$ Acibadem Mehmet Ali Aydinlar University, Faculty of Pharmacy, Department of Toxicology, 34684, Istanbul, Turkey

${ }^{6}$ Anadolu University, Faculty of Pharmacy, Department of Pharmacology, 26470, Eskişehir, Turkey ${ }^{7}$ Anadolu University, Faculty of Pharmacy, Department of Pharmacognosy, 26470, Eskişehir, Turkey ${ }^{8}$ Eastern Mediterrenean University, Faculty of Pharmacy, Famagusta, 99628, N. Cyprus, Mersin 10, Turkey

\section{ABSTRACT}

Objective: This study aimed to investigate the in vitro wound healing, anti-inflammatory, antimicrobial and antioxidant activity of Phlomis pungens Willd. extract derived from the aerial parts.

\footnotetext{
* Corresponding Author/Sorumlu Yazar: Ayşe Esra Karadağ

e-mail / e-posta: aeguler@ medipol.edu.tr, Phone / Tel.: +902164189616
} 
Material and Method: The phytochemical analysis was performed using GC-MS in order to identify the volatile components of the bioactive Hex extract. The wound healing activity of $P$. pungens extract was evaluated based on in vitro antimicrobial, antioxidant, anti-inflammatory, and, scratch activity was studied. In addition, the in vitro cytotoxicity of the extract was also evaluated.

Result and Discussion: $P$. pungens methanol extract depicted a 5-LOX inhibitory activity at $78.2 \mu \mathrm{g} / \mathrm{mL}$ $\left(I C_{50}\right)$, while the antioxidant activity by $D P P H$ radical provided an $I C_{50}=2.41 \mathrm{mg} / \mathrm{mL}$, and the ABTS radical showed $I C_{50}=3.32 \mathrm{mg} / \mathrm{mL}$, respectively. The extract showed dose-dependently anti-inflammatory activity while $L-N A M E$ and $P$. pungens methanol extract significantly decreased LPS stimulated PGE 2 production. According to the scratch assay results, all treatments led to an increase in cell migration rate with a dose-dependent effect. Our findings suggested that P. pungens methanol extract may have a role in wound healing according to the scratch test, and it is thought that its antioxidant and anti-inflammatory activity also contributed. Further evaluations are ongoing to confirm the in vitro activity under in vivo conditions.

Keywords: Cell culture, fibroblast, inflammation, Lamiaceae, macrophage

\section{ÖZ}

Amaç: Bu çalışmada, Phlomis pungens Willd. topraküstü kısımlarından elde edilen ekstrelerin in vitro yara iyileşmesi, antiinflamatuar, antimikrobiyal ve antioksidan aktivitesinin araştırlması amaçlanmıştır.

Gereç ve Yöntem: Biyoaktif hekzan ekstresinin uçucu bileşenlerini belirlemek için fitokimyasal analiz GC-MS kullanılarak yapılmıştır. P. pungens ekstresinin yara iyileştirme aktivitesi, in vitro antimikrobiyal, antioksidan, antiinflamatuar etkinlikleri değerlendirilmiş ve ek olarak ekstrenin in vitro sitotoksisitesi de değerlendirilmiştir.

Sonuç ve Tartışma: $P$. pungens metanol ekstresi, 78,2 $\mu \mathrm{g} / \mathrm{mL}^{\prime}$ de $\left(I C_{50}\right)$ 5-LOX inhibe edici aktivite gösterirken, DPPH yöntemi ile antioksidan aktivitesi $I C_{50}=2.41 \mathrm{mg} / \mathrm{mL}$ ve $A B T S I C_{50}=3.32 \mathrm{mg} / \mathrm{mL}$ olarak bulunmuştur. Ekstre, doza bağll olarak anti-inflamatuar aktivite gösterirken, L-NAME ve P. pungens metanol ekstresi, LPS ile uyarılan PGE 2 üretimini önemli ölçüde azaltmıştır. Strach metodu sonuçlarına göre doza bağlı etki ile hücre göç hızında bir artış gözlemlenmiştir. Bulgularımız, starch testine göre P. pungens metanol ekstresinin yara iyileşmesinde rol oynayabileceğini ve antioksidan ve antiinflamatuar aktivitesinin de katkıda bulunduğu düşündürmüştür. İn vivo koşullar altında in vitro aktiviteyi doğrulamak için başka değerlendirmeler devam etmektedir.

Anahtar kelimeler: Enflamasyon, fibroblast, hücre kültürü, Lamiaceae, makrofaj

\section{INTRODUCTION}

The Phlomis species with their preparations are known as wounds healing agents according to folk medicine information [1]. Furthermore, previous studies revealed that Phlomis pungens Willd. which belongs to Lamiaceae family possess a wide spectrum of pharmacological activities [2-3].

As it is well known, generally, wound repairing is progressed through four overlapping stages: hemostasis, inflammation, proliferation, and maturation [1,2]. Inflammation is a complex biological response of body tissues to harmful stimuli, such as pathogens, damaged cells, free radicals, or irritants $[3,4]$. Prolonged inflammation, known as chronic inflammation leads to simultaneous destruction and healing of the tissue derived from the inflammatory process [3] while and increased oxidative stress can hamper further the wound process. Treatments with natural products such as plant extracts can accelerate the wound healing process, given that they can eliminate microbial contamination and wound inflammation, due to their favorable properties [5].

The objective of the present study was to assess and demonstrate the pharmacological activities of $P$. pungens (PP) extract focusing on its wound healing properties. Anti-inflammatory activity was assessed by in vitro methods; lipoxygenase enzyme inhibition and lipopolysaccharide-induced 
Prostaglandin E2 and nitrite levels in RAW 264.7 cells. The wound healing activity of PP was also assessed by in vitro scratch assay.

\section{MATERIAL AND METHOD}

\section{Extract Preparation}

The aerial parts of Phlomis pungens Wild. (PP) were manually harvested at 2016 from Arguvan region (Malatya, Turkey). Faculty of Pharmacy Herbarium (Istanbul University) was contained the voucher specimen (ISTE 115025) for aerial parts. The dried-samples of PP were extracted by maceration with methanol, followed by a liquid-liquid fractionation using $n$-hexane (Hex), dichloromethane $\left(\mathrm{CH}_{2} \mathrm{Cl}_{2}\right)$, and ethyl acetate (EtOAc), respectively.

\section{Phytochemical Analyses}

GC/MS analysis of PP Hex extract was carried out with an Agilent 5975 GC-MSD system. Innowax FSC was used with helium as carrier gas. The GC analysis was performed with an Agilent 6890 N GC system. Relative percentage amounts of the separated compounds were calculated from FID chromatograms as mentioned previous studies [6].

Identification of the essential oil components was carried out by comparison of their relative retention times with those of authentic samples or by comparison of their relative retention index (RRI) to a series of n-alkanes. The components of essential oils were identified by comparison of their mass spectra with those in the Baser Library of Essential Oil Constituents, Wiley GC/MS Library, MassFinder Library [6].

\section{In vitro Antioxidant Assays}

\section{DPPH Radical Scavenging Assay}

Antioxidant capacity of PP methanol extract was examined with DPPH (2, 2-diphenyl-1picrylhydrazyl) [7]. Optical density was measured spectrophotometrically at $517 \mathrm{~nm}$. The analysis was compared with ascorbic acid as standard reference, according to our previous work [8].

\section{ABTS Radical Scavenging Assay}

The antioxidant effect of the extracts were detected using ABTS (2, 2-azino-bis-3 ethyl benzathiazoline-6-sulphonic acid) radical radical cations decolourisation assay according to protocol of Re et al. [9]. Assays were conducted comparatively using standard reference substances such Trolox, as per in our previous work [8]. 


\section{Total Phenolic Content}

The total phenolic content of PP methanol extract was determined using the Folin-Ciocalteu method. The optical density was read at $765 \mathrm{~nm}$. A calibration curve $\left(R^{2}=0.9816\right)$ was used to determine the total phenolics compounds [10].

\section{Antimicrobial Studies}

The antimicrobial properties of PP methanol extract was found out using the broth microdilution test that was conducted to the method of Clinical and Laboratory Standards Institute. Pseudomonas aeruginosa ATCC 10145, Staphylococcus epidermidis ATCC 14990, Staphylococcus aureus ATCC 6538, Escherichia coli NRLL B-3008, and Candida albicans ATCC 64548 strains were investigated in this work. Mueller Hinton Broth was used for antibacterial assays whilst RPMI broth was used for antifungal assay.

\section{Lipoxygenase (LOX) Inhibition Assay}

A modified spectrophotometric method which was formed by Baylac and Recine, was used to determine the 5-lipoxygenase (5-LOX) inhibition potential of the PP methanol, EtOAc, $\mathrm{CH}_{2} \mathrm{Cl}_{2}$ and $\mathrm{Hex}$ extracts [11]. Herein, a nordihydroguaiaretic acid (NDGA), a known inhibitor of soybean lipoxygenase, was used as a reference standard drug.

\section{Cytotoxicity}

\section{Cell Culture}

The L929 mouse fibroblast and RAW 264.7 murine macrophage cell lines were cultured in $\operatorname{DMEM}(10 \%$ FBS, v/v) and supplemented with $1 \%$ (v/v) penicillin-streptomycin. Cells were incubated at $37^{\circ} \mathrm{C}$ and $5 \% \mathrm{CO}_{2}$ and were passaged out every $2-3$ days.

\section{Cytotoxicity by MTT Assay}

MTT [3-[4.5-dimethylazol-2-yl]-2.5-diphenyl-tetrazolium bromide] assay was performed to assess the cytotoxicity profile of PP on RAW264.7 and L929. Concisely, RAW264.7 and L929 cells were plated and incubated in a $5 \% \mathrm{CO}_{2}$ atmosphere at $37^{\circ} \mathrm{C}$ for $24 \mathrm{~h}$ to form a confluent layer. Cells were treated with various concentrations $(0.125-1 \mathrm{mg} / \mathrm{mL})$ of PP freshly diluted with cell culture medium. After 1 day incubation $0.5 \mathrm{mg} / \mathrm{mL}$ MTT was applied to per well and continued with $2 \mathrm{~h}$ incubation at $37^{\circ} \mathrm{C}$. A UV-spectrophotometric plate reader was used to measure the absorbance of the blue formazan at $570 \mathrm{~nm}$. (Thermo, Finland) [12].

\section{Anti-inflammatory Activity}

Griess assay was used to detect the anti-inflammatory potential of PP methanol extract on RAW 264.7 cell through stabile metabolite of NO, nitrite level [12]. After 24h incubation, RAW 264.7 cells 
were pre-treated with various concentrations of $\mathrm{PP}$ for $2 \mathrm{~h}$ followed by stimulation for $22 \mathrm{~h}$ with $1 \mathrm{mg} / \mathrm{mL}$ lipopolysaccharide (LPS extracted from E. coli $0111: \mathrm{B} 4$ ) at $37^{\circ} \mathrm{C}$ in an incubator with $5 \% \mathrm{CO}_{2}$.

Nitrate level was estimated in cell supernatants using Griess reagents in each well of a 96-well plate. Absorbance was measured at a wavelength of $540 \mathrm{~nm}$ in a microplate reader (Multiskan Ascent, Finland). NO production was measured as the concentration of nitrite by comparing against a standard curve generated using $\mathrm{NaNO}_{2} .0 .1 \mathrm{mg} / \mathrm{mL}$ L-NAME (L-NG-Nitro arginine methyl ester), a nonselective nitric oxide synthase inhibitor, was served as a control.

Anti-inflammatory activity of PP methanol extract was also supported with Prostaglandin $\mathrm{E}_{2}$ The anti-inflammatory effect of the PP methanol extract was also verified using the Prostaglandin $\mathrm{E}_{2}$ ELISA Kit (Abcam, UK) and $100 \mu \mathrm{L}$ of cell supernatants treated with LPS and compounds, as instructed by the manufacturer.

\section{In Vitro Wound Healing Activity by Scratch Assay}

The wound healing properties of the PP extract were assessed by scratch assay in vitro by assessing the migration rate of the L929 mice fibroblast cell line within 24h. Briefly, cells were seeded in 24-well cell culture plate. After the cells had nearly formed a confluent cell monolayer, a linear wound was generated in the monolayer using a sterile $100 \mu \mathrm{L}$ plastic pipette tip. Any cellular debris was removed by washing the wells with phosphate buffer saline (PBS).

Different concentrations $(0.125-0.5 \mathrm{mg} / \mathrm{mL})$ of PP extracts were administered to each scratched well and incubated at $37^{\circ} \mathrm{C}$ and $5 \% \mathrm{CO}_{2}$ in humidified atmosphere.

Directly after generating the scratch $(0 \mathrm{~h})$ and after 8 , and $24 \mathrm{~h}$ (end point time) microscopic images of the same area of the respective scratch were taken (AxioCam, Germany).

\section{Statistical Analysis}

Statistical analyses were evaluated with GraphPad Prism 7.0 program (California, USA). Values for $\mathrm{p}<0.05$ were considered statistically significant. T-test was used to compare the significant differences between groups.

\section{RESULT AND DISCUSSION}

Hex extract yield $(17.9 \mathrm{~g} ; 41.7 \%)$ was highest over total methanol extract (43 g). The yields of EtOAc and $\mathrm{CH}_{2} \mathrm{Cl}_{2}$ extracts were $16.5 \%$ and $3.7 \%$, respectively. The Hex fraction of Phlomis pungens Willd. (PP) was examined by GC-MS and hexadecanoic acid (38.7\%) was determined as a major constituent. Other compounds found in the extract were benzophenone (19.3\%), methyl decanoate (15.6\%), and methyl pentadecanoate (13.6\%), respectively. 
In further, the PP methanol extract displayed moderate in vitro antioxidant capacity compared to Trolox $(0.015 \mathrm{mg} / \mathrm{mL})$ and ascorbic acid $(0.002 \mathrm{mg} / \mathrm{mL})$, against ABTS $\left(\mathrm{IC}_{50}=2.32 \mathrm{mg} / \mathrm{mL}\right)$ and DPPH $\left(\mathrm{IC}_{50}=1.41 \mathrm{mg} / \mathrm{mL}\right)$ free radicals. The entire phenolic constituents of PP methanol extract was $2967 \mathrm{mg}$ of gallic acid/100g extract.

Moreover, the antimicrobial activity of the different extracts of PP was against tested microorganisms. Table 1 shows the antimicrobial activity of PP extracts, and the reference compounds versus the tested microorganisms. The PP methanol and Hex extracts showed antifungal activity against the C. albicans $(250 \mu \mathrm{g} / \mathrm{mL})$. C. albicans was more responsive to the PP, while the tested bacteria were resistant.

$\mathrm{IC}_{50}$ values of lipoxygenase inhibitory activities of methanol, EtOAc, $\mathrm{CH}_{2} \mathrm{Cl}_{2}$ and $\mathrm{Hex}$ extracts of PP were $27 \pm 2.8,77.4 \pm 1.5,32 \pm 0.7,26.1 \pm 1.2 \mu \mathrm{g} / \mathrm{mL}$, respectively as compared to NDGA $(3.2 \pm 0.9$ $\mu \mathrm{g} / \mathrm{mL})$.

The cytotoxic effects of the PP methanol extract on L929 and RAW264.7 cell lines were demonstrated in Figure 1 as cell viability \% compared to control. According to MTT results PP did not exhibit cytotoxicity on L929 and RAW264.7 cell lines at concentrations between $0.125-1 \mathrm{mg} / \mathrm{mL}$ (Fig. 1A). Furthermore, a notable increased proliferation of RAW264.7 cells was observed with PP in a dose dependent manner (Fig. 1B).

In vitro anti-inflammatory capacity of $\mathrm{PP}$ was assessed with nitrite level and several concentrations (between $0.125-1 \mathrm{mg} / \mathrm{mL}$ ) of the extract were tested based on MTT results which showed no cytotoxicity for these doses. As seen in Figure 2, PP showed dose-dependently anti-inflammatory activity. In addition, $0.25,0.5$ and $1 \mathrm{mg} / \mathrm{mL}$ concentrations of the extract have showed a significant reduction in LPS-induced nitrite production in RAW 264.7 cells. Moreover, nitrite inhibition \% of related concentrations were found as $18.68 \%, 21.33 \%$, and $40.16 \%$ compared to LPS, respectively. The analgesic activity of nitrite reducing doses of PP $(0.25-1 \mathrm{mg} / \mathrm{mL})$ was determined by the $\mathrm{PGE}_{2}$ level. As seen in Figure 3, L-NAME $(0.1 \mathrm{mg} / \mathrm{mL})$ and PP $(0.25-1 \mathrm{mg} / \mathrm{mL})$ significantly decreased LPS stimulated $\mathrm{PGE}_{2}$ production. The highest $\mathrm{PGE}_{2}$ inhibition was seen with $0.125 \mathrm{mg} / \mathrm{mL}$ of the extract $(\mathrm{p}<0.05)$.

The wound healing properties of the PP were assessed through in vitro scratch assay. The cell proliferation and migration rate of groups were recorded at time 0,8 , and $24 \mathrm{~h}$. In Figure 4, microscopical scratch images of groups treated with different concentrations of PP extract at time 0,8 , and $24 \mathrm{~h}$ were given. According to the results, all treatments have led to an increase in cell migration rate in a dosedependent manner in comparison to the control. In Figure 5, the relative wound healing activity of each group was given. As it was expected, the ration of in vitro wound healing is interestingly high since wound healing was analogous with the dose of the extract and above $90 \%$. 
Table 1. Minimum inhibitory concentration (MIC) of antimicrobial activity in various extracts of $P$. pungens $(\mu \mathrm{g} / \mathrm{mL})$

\begin{tabular}{|c|c|c|c|c|c|}
\hline & 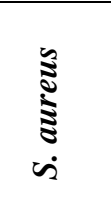 & 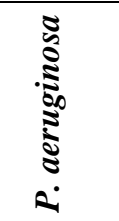 & 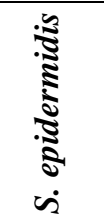 & $\begin{array}{l}\dot{\tilde{s}} \\
\dot{8} \\
\dot{y}\end{array}$ & 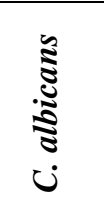 \\
\hline Methanol & $>1000$ & 1000 & $>1000$ & $>1000$ & 250 \\
\hline Ethyl acetate & 500 & 1000 & $>1000$ & 1000 & $>1000$ \\
\hline Dichloromethane & $>1000$ & $>1000$ & $>1000$ & $>1000$ & $>1000$ \\
\hline$n$-hexane & 500 & 1000 & 1000 & 1000 & 250 \\
\hline Tetracycline & 0.25 & $>16$ & $>16$ & 16 & \\
\hline Ketoconazole & & & & & 0.25 \\
\hline
\end{tabular}

A

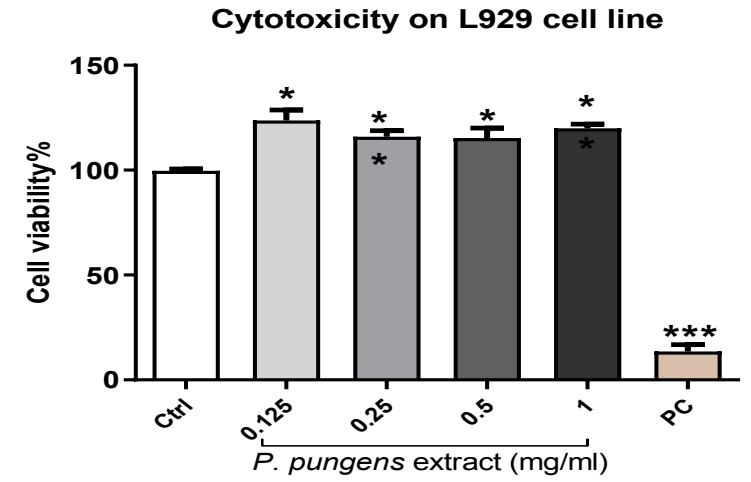

B

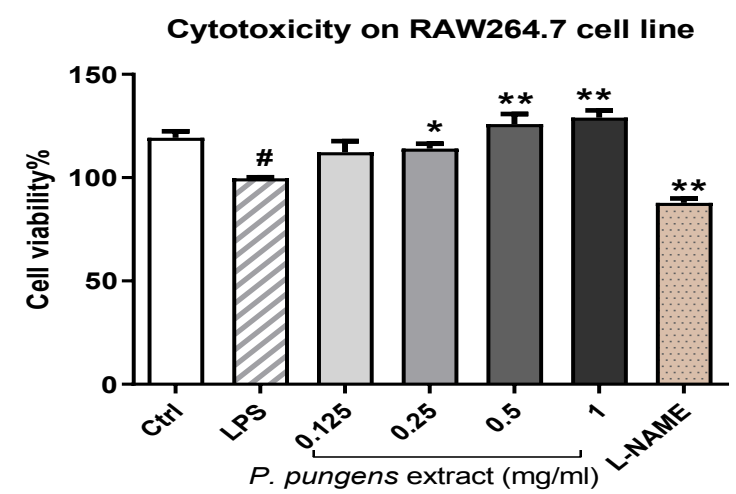

Figure 1. Cytotoxicity profile of PP on L929 (A) and RAW264.7 (B) cell lines by MTT assay Data were expressed as mean \pm SD compared to control. (A) Statistically significant difference; ${ }^{*} \mathrm{p}<0.05,{ }^{* *} \mathrm{p}<0.01,{ }^{* * *} \mathrm{p}<0.001$ vs. control (B) All groups except Ctrl were treated with LPS. Statistically significant difference: ${ }^{*} \mathrm{p}<0.05,{ }^{*} \mathrm{p}<<0.01$ vs. LPS and the significant difference between Ctrl and LPS were defined with ${ }^{\#} \mathrm{p}<0.05$. Ctrl: Group treated with DMEM; L-NAME: L-N ${ }^{\mathrm{G}}$ Nitro arginine methyl ester $(0.1 \mathrm{mg} / \mathrm{mL})$; PC: $20 \%$ (v/v) DMSO.

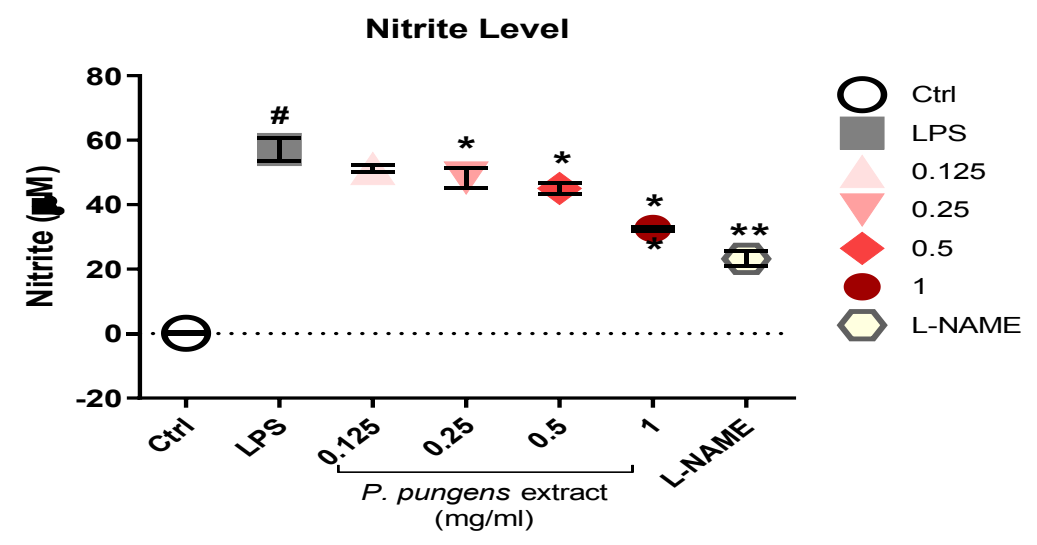

Figure 2. Inhibition of nitrite production by PP in LPS-induced RAW264.7 cells

${ }^{*} \mathrm{p}<0.05,{ }^{* *} \mathrm{p}<0.01$; significant difference from LPS and the significant difference between Ctrl and LPS were defined with $\# \mathrm{p}<0.01$. Data were expressed as mean $\pm \mathrm{SD}$ compared to LPS. Ctrl: Group treated with DMEM; L-NAME: L-N ${ }^{\mathrm{G}}-\mathrm{Nitro}$ arginine methyl ester $(0.1 \mathrm{mg} / \mathrm{mL})$. 


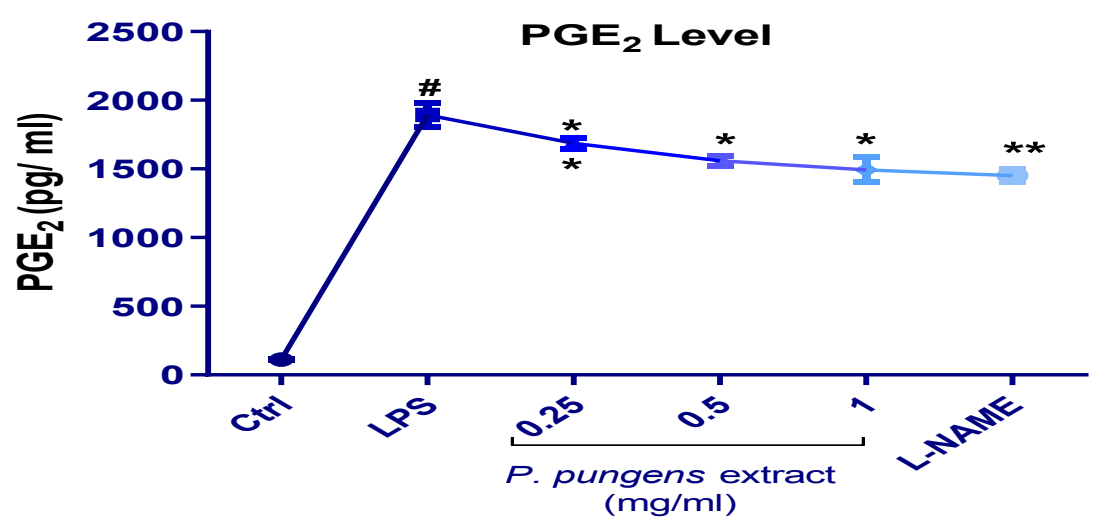

Figure 3. Inhibition of LPS-induced PGE2 production by PP

${ }^{*} \mathrm{p}<0.05, * * \mathrm{p}<0.01$; significant difference from LPS and the significant difference between Ctrl and LPS were defined with $\# \mathrm{p}<0.001$. The outcomes were illustrated as mean \pm SD compared to LPS. Ctrl: Group treated with DMEM; L-NAME: L-NGNitro arginine methyl ester $(0.1 \mathrm{mg} / \mathrm{mL})$.

The present study revealed the antimicrobial, antioxidant, anti-inflammatory and wound healing activity of Phlomis pungens Willd. (PP) methanol extract.

GC-MS analysis proved the presence of hexadecanoic acid, which is a saturatted fatty acid known for various pharmacological activities, such as anti-inflammatory [13] by downregulating proinflammatory cytokines. Hence, hexadecanoic acid can be considered as the major component responsible for anti-inflammatory activity of PP as it was quoted from previous studies [14]. However, although, in the past works, the antioxidant activity evaluation was performed with PP methanol extract, the derived results in this study differed from the previous one $[15,16]$. Consequently, it can be said that the parameters such as flora and time of harvest where the plant grows can change the secondary metabolites of the plant and therefore its activity.

The antimicrobial studies reveal that the PP did not show any remarkable antibacterial effect but depicted an interesting antifungal property. C. albicans have been found in surgical wounds which are prone to become chronical; considerably, the extract can be also applied for fungi contaminated wounds.

It is well known that lipid mediators originated by 5-LOX metabolism can activate both pro- and anti-inflammatory pathways. However, their role during wound healing has not fully understand but seems to be important in wound healing [17]. Several experiments have shown that the absence of 5lipoxygenase triggers rapid dermal wound closing. [17,18]. In this work, the methanol and Hex extracts showed moderate inhibitory activity to 5-LOX which however is in the acceptable limits.

Cell viability which can be evaluated by MTT assay is among the most important studies for wound healing applications. It is well reported that wound systems which are toxic to microbial cells could potentially be toxic to the skin cells. This cytotoxicity could affect the cells in various pathways such as stopping their growth, divide and inducing their necrosis due to cell lysis. Considerably, these facts can reduce the viability, proliferation, and mobility of the cells and further delay the wound healing 
activity [19]. As it was expected, the developed extract did not depict any signs of cytotoxicity which is very promising.

The raised level of $\mathrm{PGE}_{2}$ is a sign of progression of inflammation in several cell types and variant inflammatory disorders. Furthermore, decreased level of PGs in fetal skin tissue might display a less severe inflammatory response, which results in little scar formation after wound healing [20]. In this study, PP presented dose-dependently anti-inflammatory activity which is very important for wound healing applications. Finally, the inhibition of prostaglandin production has been associated with reduced pain; hence, herein the PP showed inhibition of LPS-induced $\mathrm{PGE}_{2}$ production which can potentially leads to reduced pain and improved anti-inflammatory activity.
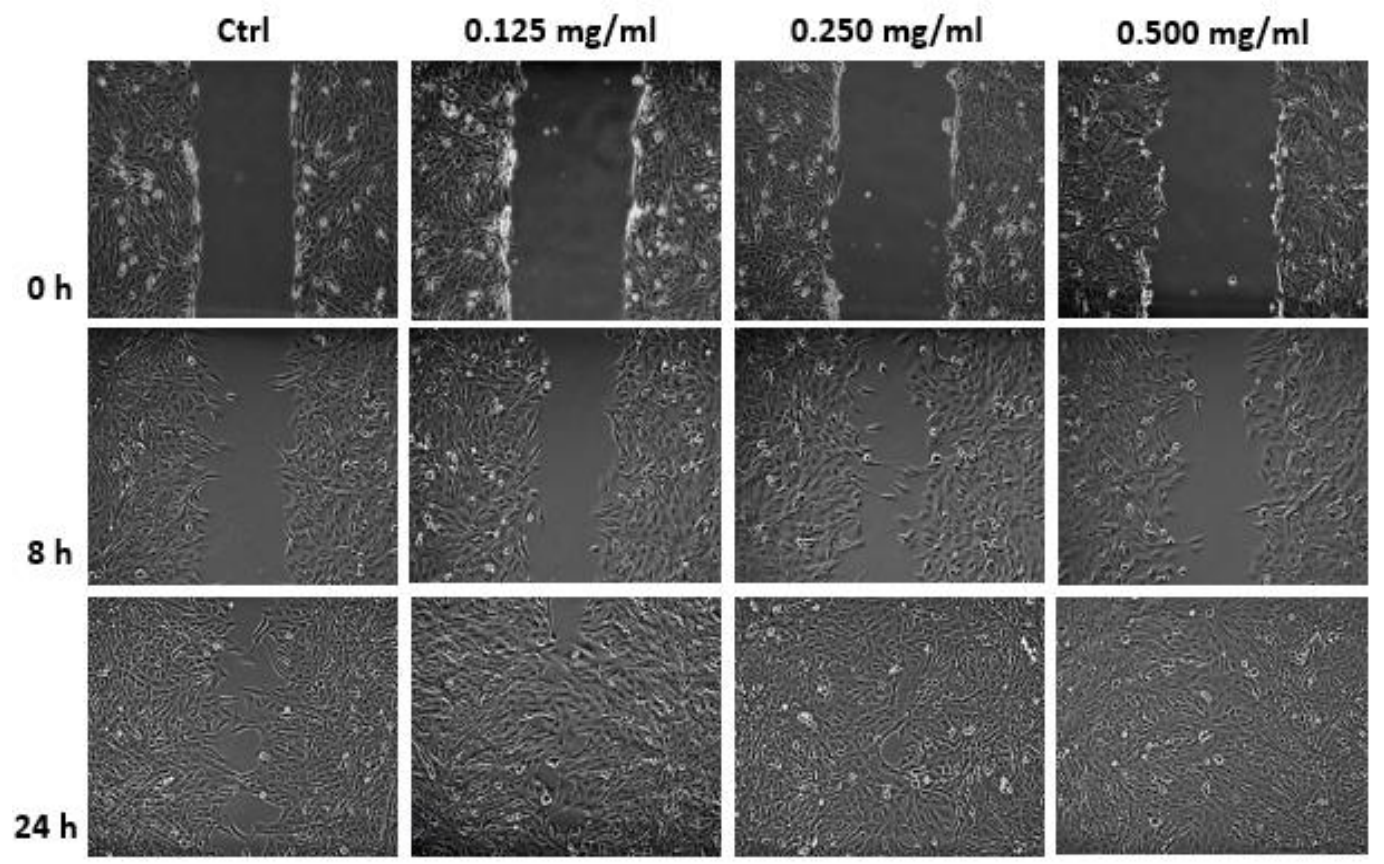

Figure 4. Microscopical figures of in vitro wound healing activity of $P$. pungens extract on L929 cell line

Scratches formed and images were taken with a microscope at 10 magnification at 0,8 , and $24 \mathrm{~h}$. Ctrl: Control group treated with medium.

Fibroblasts perform a crucial function by proliferating, spreading to the lesion site, and stimulating the formation of new extracellular matrix in the initial stages of wound healing [21]. Therefore, fibroblast cell lines such as L929 have been widely employed to assess wound healing activity in vitro [22]. The initial steps of wound healing are activation, proliferation, and migration of fibroblasts during which multiple cell types and other micro environmental factors seems to be involved. Scratch assay has been widely applied to study in vitro the wound healing applicability of naturally derived plants; it was found that wound contraction was desirable when the extract applied to L929 fibroblast cell lines. 


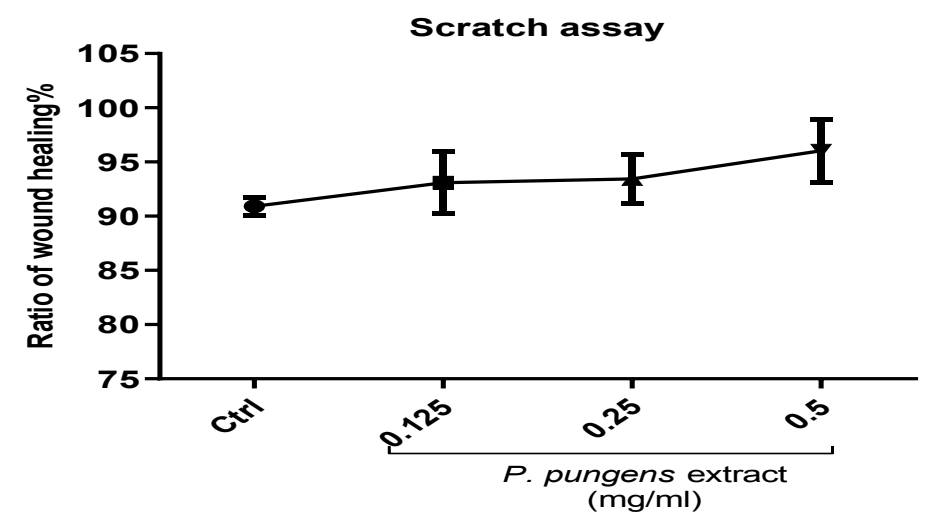

Figure 5. Wound healing effect of $P$. pungens extract on L929 cell

Relative wound healing according to the closed gap between scratch margins within $24 \mathrm{~h}$ for each group. Ctrl: Control group treated with medium.

Present investigations concluded that PP demonstrated in vitro antimicrobial, anti-inflammatory, and antioxidant properties. According to our results, it could be suggested that PP contributes greatly to in vitro wound healing process owing to its antioxidant and anti-inflammatory activity. Due to the wound repairing (in vitro) behavior of the $P$. pungens extract further investigation on animal models or humans could assure the possible application of the extract for wound healing. PP extract may have a role in wound healing with the scratch test, and it is thought that its antioxidant and anti-inflammatory activity also contributes to this effect. It is thought that this study related to the effects of PP extract will lead to new studies.

\section{ACKNOWLEDGEMENTS}

The authors are grateful to Prof. Dr. Şükran Kültür for identifying confirmation and Muhammet Karadağ for harvesting the plant material. This research project was supported by Anadolu University Scientific Research Projects (Project No:1807S259).

\section{AUTHOR CONTRIBUTIONS}

Conception: M.E.O., A.E.K., F.D.; Design: M.E.O., A.E.K., F.D.; Supervision: F.D.; Resources: F.D., B.D.; Materials: A.E.K., H.S., R.R.; Data collection and/or processing: A.E.K., R.R., H.S.; Analysis and/or interpretation: B.D., R.R., A.E.K.; Literature search: A.E.K., M.E.O.; Writing manuscript: M.E.O., A.E.K.; Critical review: F.D., B.D.; Other: -

\section{CONFLICT OF INTEREST}

The authors declare no conflict of interest. 


\section{ETHICS COMMITTEE APPROVAL}

The authors declare that the ethics committee approval is not required for this study.

\section{REFERENCES}

1. Tanrıverdi, S.T., Suat, B., Azizoğlu, E., Köse, F.A., Özer, Ö. (2018). In-vitro evaluation of dexpanthenol-loaded nanofiber mats for wound healing. Tropical Journal of Pharmaceutical Research, 17(3), 387-394. [CrossRef]

2. Chingwaru, C., Bagar, T., Maroyi, A., Kapewangolo, P.T., Chingwaru, W. (2019). Wound healing potential of selected Southern African medicinal plants: A review. Journal of Herbal Medicine, 17-18, 100263. [CrossRef]

3. Muthachan, T., Tewtrakul, S. (2019). Anti-inflammatory and wound healing effects of gel containing Kaempferia marginata extract. Journal of Ethnopharmacology, 240, 111964. [CrossRef]

4. Ghuman, S., Ncube, B., Finnie, J.F., McGaw, L.J., Mfotie Njoya, E., Coopoosamy, R.M., Van Staden, J. (2019). Antioxidant, anti-inflammatory and wound healing properties of medicinal plant extracts used to treat wounds and dermatological disorders. South African Journal of Botany, 126, 232-240. [CrossRef]

5. Okur, M.E., Karantas, I.D., Şenyiğit, Z., Okur, N.Ü., Siafaka, P.I. (2020). Recent trends on wound management; new therapeutic choices based on polymeric carriers. Asian Journal of Pharmaceutical Sciences, 15(6), 661-684. [CrossRef]

6. Demirci, B., Baser, K.H.C., Dadandi, M.Y. (2006). Composition of the Essential Oils of Phlomis rigida Labill. and P. samia L. Journal of Essential Oil Research, 18(3), 328-331. [CrossRef]

7. Blois, M.S. (1958). Antioxidant determinations by the use of a stable free radical. Nature, 181, 1199-1200. [CrossRef]

8. Okur, M.E., Ayla, Ş., Çiçek Polat, D., Günal, M.Y., Yoltaş, A., Biçeroğlu, Ö. (2018). Novel insight into wound healing properties of methanol extract of Capparis ovata Desf. var. palaestina Zohary fruits. Journal of Pharmacy and Pharmacology, 70(10), 1401-1413. [CrossRef]

9. Re, R., Pellegrini, N., Proteggente, A., Pannala, A., Yang, M., Rice-Evans, C. (1999). Antioxidant activity applying an improved ABTS radical cation decolorization assay. Free Radical Biology and Medicine, 26(9-10), 1231-1237. [CrossRef]

10. Spanos, G.A., Wrolstad, R.E. (1990). Influence of processing and storage on the phenolic composition of Thompson Seedless grape juice. Journal of Agricultural and Food Chemistry, 38(7), 1565-1571. [CrossRef]

11. Baylac, S., Racine, P. (2003). Inhibition of 5-lipoxygenase by essential oils and other natural fragment extracts. International Journal of Aromatherapy, 13(2-3), 138-142. [CrossRef]

12. Reis, R., Sipahi, H., Zeybekoğlu, G., Çelik, N., Kırmızıbekmez, H., Kaklıkkaya, N., Aydın, A. (2018). Hydroxytyrosol: The phytochemical responsible for bioactivity of traditionally used Olive 
Pits. Euroasian Journal of Hepatogastroenterology, 8(2), 126-132. [CrossRef]

13. Aparna, V., Dileep, K.V., Mandal, P.K., Karthe, P., Sadasivan, C., Haridas, M. (2012). AntiInflammatory Property of n-Hexadecanoic Acid: Structural Evidence and Kinetic Assessment. Chemical Biology\&Drug Design, 80(3), 434-439. [CrossRef]

14. Okur, M.E., Karadă̆, A.E., Üstündağ Okur, N., Özhan, Y., Sipahi, H., Ayla, Ş., Daylan, B., Demirci, B., Demirci, F. (2020). In Vivo Wound Healing and In Vitro Anti-Inflammatory Activity Evaluation of Phlomis russeliana Extract Gel Formulations. Molecules, 25(11), 2695. [CrossRef]

15. Sarikurkcu, C., Uren, M. C., Tepe, B., Cengiz, M., Kocak, M.S. (2014). Phenolic content, enzyme inhibitory and antioxidative activity potentials of Phlomis nissolii and $\mathrm{P}$. pungens var. pungens. Industrial Crops and Products, 62, 333-340. [CrossRef]

16. Taskin, T., Bulut, G., Hazar, A.N. (2018). Antioxidant and anti-inflammatory activities of Phlomis pungens and Coridothymus capitatus. Marmara Pharmaceutical Journal, 22(1), 80-85. [CrossRef]

17. Brogliato, A.R., Moor, A.N., Kesl, S.L., Guilherme, R.F., Georgii, J.L., Peters-Golden, M., Canetti, C., Gould, L.J., Benjamim, C.F. (2014). Critical Role of 5-Lipoxygenase and Heme Oxygenase-1 in Wound Healing. Journal of Investigative Dermatology, 134(5), 1436-1445. [CrossRef]

18. Guimarães, F.R., Sales-Campos, H., Nardini, V., da Costa, T.A., Fonseca, M.T.C., Júnior, V.R., Sorgi, C.A., da Silva, J.S., Chica, J.E.L., Faccioli, L.H. (2018). The inhibition of 5-Lipoxygenase (5-LO) products leukotriene B4 (LTB 4) and cysteinyl leukotrienes (cysLTs) modulates the inflammatory response and improves cutaneous wound healing. Clinical Immunology, 190, 7483. [CrossRef]

19. Chen, R., Salisbury, A., Percival, S.L. (2019). In vitro cellular viability studies on a concentrated surfactant- based wound dressing. International Wound Journal, 16(3), 703-712. [CrossRef]

20. Su, W.H., Cheng, M.H., Lee, W.L., Tsou, T.S., Chang, W.H., Chen, C.S., Wang, P.H. (2010). Nonsteroidal Anti-Inflammatory Drugs for Wounds: Pain Relief or Excessive Scar Formation? Mediators of Inflammation, 2010, 413238. [CrossRef]

21. Li, W., Fan, J., Chen, M., Guan, S., Sawcer, D., Bokoch, G.M., Woodley, D.T. (2004). Mechanism of Human Dermal Fibroblast Migration Driven by Type I Collagen and Plateletderived Growth Factor-BB. Molecular Biology of the Cell, 15(1), 294-309. [CrossRef]

22. Bolla, S.R., Mohammed Al-Subaie, A., Yousuf Al-Jindan, R., Papayya Balakrishna, J., Kanchi Ravi, P., Veeraraghavan, V.P., Arumugam Pillai, A., Gollapalli, S.S.R., Palpath Joseph, J., Surapaneni, K.M. (2019). In vitro wound healing potency of methanolic leaf extract of Aristolochia saccata is possibly mediated by its stimulatory effect on collagen-1 expression. Heliyon, 5(5), e01648. [CrossRef] 